\title{
Effect of Micronutrients on Growth and Yield of Sweet Sorghum under Tarai Region of Uttarakhand, India
}

\author{
Brajkishor Prajapati $^{1^{*}}$ and Kewalanand ${ }^{2}$ \\ ${ }^{1}$ Department of Agronomy, KVK, Balaghat, M.P., India \\ ${ }^{2}$ Department of Agronomy, College of Agriculture, GBPUA\&T, Pantnagar-263145, India \\ *Corresponding author
}

\section{A B S T R A C T}

\section{Keywords}

Crude protein, Green fodder, Micronutrients, Sweet sorghum

Article Info

Accepted:

15 November 2019 Available Online:

10 December 2019
Field experiment was conducted to evaluate response of micronutrient on growth and yield of sweet sorghum at Instructional Dairy Farm, G.B.P.U.A. \& T., Pantnagar, U.S.Nagar, Uttarakhand during Kharif seasons of 2012 and 2013. The soil of experimental site was silty clay loam having $7.7 \mathrm{pH}, 0.81 \%$ organic carbon, 273.35, 25.69 and $240 \mathrm{~kg} / \mathrm{ha}$ available N, P and K respectively. The experiment was laid out in Randomized Block Design with 3 replications and ten treatments consisted of control, NPK 120:60:40 kg/ha (RDF), RDF+ZnSO $425 \mathrm{~kg} / \mathrm{ha}, \quad \mathrm{RDF}+\mathrm{FeSO}{ }_{4} 25 \mathrm{~kg} / \mathrm{ha}$, $\mathrm{RDF}+0.2 \% \mathrm{ZnSO}_{4}$ spray at 15 and $30 \mathrm{DAS}, \mathrm{RDF}+0.4 \% \mathrm{FeSO}_{4}$ spray at 15 and 30 $\mathrm{DAS}, \mathrm{RDF}+0.2 \% \mathrm{ZnSO}_{4}+0.4 \% \mathrm{FeSO}_{4}$ spray at 15 and $30 \mathrm{DAS}, \mathrm{RDF}+\mathrm{ZnSO}_{4} 15$ $\mathrm{kg} / \mathrm{ha}+0.2 \% \mathrm{ZnSO}_{4}$ spray at 15 and $30 \mathrm{DAS}, \mathrm{RDF}+\mathrm{FeSO}{ }_{4} 15 \mathrm{~kg} / \mathrm{ha}+0.4 \% \mathrm{FeSO}_{4}$ spray at 15 and $30 \mathrm{DAS}$ and $\mathrm{RDF}+\mathrm{ZnSO}_{4} 15 \mathrm{~kg} / \mathrm{ha}+\mathrm{FeSO}_{4} 15 \mathrm{~kg} / \mathrm{ha}$ as soil application. RDF (NPK 120:60:40 kg/ha) in combination with $\mathrm{ZnSO}_{4} 15 \mathrm{~kg} / \mathrm{ha}+\mathrm{FeSO}_{4} 15 \mathrm{~kg} / \mathrm{ha}$ as soil application showed maximum growth attributes characters (plant height, L:S, stem diameter), dry matter content, crude protein content, green fodder yield of 613.36 and $624.63 \mathrm{q} / \mathrm{ha}$, dry fodder yield of $170.39,177.21 \mathrm{q} / \mathrm{ha}$ as well as crude protein yield 16.65 and $17.44 \mathrm{q} / \mathrm{ha}$, net and B:C ratio during 2012 and 2013, respectively followed by $\mathrm{RDF}+\mathrm{ZnSO}_{4} 25 \mathrm{~kg} / \mathrm{ha}$.

\section{Introduction}

Sweet sorghum is a $\mathrm{C}_{4}$ cereal crop with high photosynthetic efficiency and the principal dryland crop grown in India for food, feed and fodder for livestock. It has good characteristics such as resistance to drought, resistance to poor drainage, tolerates a $\mathrm{pH}$ range of 5.0 to 8.5 , some degree salinity resistance and high biomass yield etc. In addition, the fodder and stover is fed to animals for milk and being used as industrial raw material for bio fuel (Koeppen et al., 2009), refining sugar, paper making etc. Sugars content in sweet sorghum stalk juice mostly were sucrose and invert sugars which invert sugars are included glucose, fructose, maltose and xylose. Sweet sorghum being 
highly exhaustive in nature, demands good nutrient management. Among different nutrients micronutrients especially zinc ( $\mathrm{Zn})$ and iron $(\mathrm{Fe})$ plays an important role in production of quality fodder. Application of micronutrient fertilizers through soil application is the most efficient and economical method of getting these nutrients into the crops (Jat et al., 2014). Fertifortification, which involves fertilizing crops with micronutrient, gives immediate results by increasing the concentration of micronutrients in plant with an increase in yield. Foliar feeding results in rapid absorption and is less costly (El-Fouly and El-Saxed, 1997). $\mathrm{Zn}$ is essential for synthesis of tryptophan, an amino acid (precursor of indole acetic acid), which is transported from the endosperm of the seed through the xylem towards coleoptiles tips and young leaves. $\mathrm{Zn}$ influences $\mathrm{N}$ metabolism and uptake, protein quality, photosynthesis, chlorophyll synthesis, carbon anhydrase activity, resistance to abiotic and biotic stresses and protection against oxidative damage (Pandey et al., 2002). Role of iron is its catalytic function in biological oxidation and reduction in plants like oxidative photophosphorylation during cell respiration. Iron is a constituent of a large number of metabolically active compounds like cytochromes, heme and nonheme enzymes and other functional metalloproteins (Rathod et al., 2005). Very limited work has been carried out on micronutrient nutrition of sweet sorghum. Therefore, this study was conducted to find out effect of soil and foliar feeding of micronutrients at different growth stages of crop on growth and yield of sweet sorghum.

\section{Materials and Methods}

Field experiment was conducted to evaluate response of micronutrient on growth and yield of sweet sorghum at Instructional Dairy Farm, G.B.P.U.A. \& T., Pantnagar, U.S. Nagar, Uttarakhand during Kharif seasons of 2012 and 2013. The soil of experimental site was silty clay loam having $7.7 \mathrm{pH}, 0.81 \%$ organic carbon (Walkley and Black, 1934), 273.35 (Subbiah and Asija, 1956), 25.69 (Olsen et al., 1954) and 240 (Jackson, 1973) kg/ha available $\mathrm{N}, \mathrm{P}$ and $\mathrm{K}$, respectively. The experiment was laid out in Randomized Block Design with 3 replications and ten treatments consisted of control, NPK 120:60:40 kg/ha (RDF), $\mathrm{RDF}+\mathrm{ZnSO}_{4} 25 \mathrm{~kg} / \mathrm{ha}, \mathrm{RDF}+\mathrm{FeSO}_{4} 25 \mathrm{~kg} / \mathrm{ha}$, $\mathrm{RDF}+0.2 \% \quad \mathrm{ZnSO}_{4}$ spray at $15 \& 30 \quad$ DAS, $\mathrm{RDF}+0.4 \% \quad \mathrm{FeSO}_{4}$ spray at $15 \& 30$ DAS, $\mathrm{RDF}+0.2 \% \mathrm{ZnSO}_{4}+0.4 \% \mathrm{FeSO}_{4}$ spray at $15 \&$ $30 \mathrm{DAS}, \mathrm{RDF}+\mathrm{ZnSO}_{4} 15 \mathrm{~kg} / \mathrm{ha}+0.2 \% \mathrm{ZnSO}_{4}$ spray at $15 \& 30$ DAS, $\mathrm{RDF}+\mathrm{FeSO}_{4} \quad 15$ $\mathrm{kg} / \mathrm{ha}+0.4 \% \mathrm{FeSO}_{4}$ spray at $15 \& 30 \mathrm{DAS}$ and $\mathrm{RDF}+\mathrm{ZnSO}_{4} 15 \mathrm{~kg} / \mathrm{ha}+\mathrm{FeSO}_{4} 15 \mathrm{~kg} / \mathrm{ha}$ as soil application. The recommended doses of fertilizers (RDF) 120, 60 and $40 \mathrm{~kg} / \mathrm{ha}$ nitrogen $(\mathrm{N}), \mathrm{P}_{2} \mathrm{O}_{5}$ and $\mathrm{K}_{2} \mathrm{O}$, respectively. Half of the nitrogen and full dose of $\mathrm{P}$ and $\mathrm{K}$ was applied at the time of sowing as basal. Rest of the nitrogen was applied in two equal doses each at 30 and 50 days after sowing of sweet sorghum. The crop was sown in rows opened at $40 \mathrm{~cm}$ apart with $15 \mathrm{~cm}$ plant to plant spacing. At harvest, $500 \mathrm{~g}$ fresh sample from each plot was taken to determine dry matter content. The samples were dried at $70^{\circ} \mathrm{C} \pm 2$ in hot air oven for moisture loss. The finely grinded dry samples using $2 \mathrm{~mm}$ sieve were used for nitrogen content by Micro kjeldahl method (Jackson, 1973). The crude protein content was determined by multiplying nitrogen per cent with 6.25 (AOAC, 1965).

\section{Results and Discussion}

Data presented in Table 1 revealed that plant height, dry matter and crude protein content were influenced significantly by soil and foliar application of micronutrients along with RDF. The maximum plant height (360.0 in 2012 and 370.0 in 2013), stem diameter (1.58 in 2012 and 1.63 in 2013) and L:S ratio (0.30 and 0.34 in 2012 and 2013, respectively) were recorded 
due to $\mathrm{RDF}+\mathrm{ZnSO}_{4} 15 \mathrm{~kg} / \mathrm{ha}+\mathrm{FeSO}_{4} 15 \mathrm{~kg} / \mathrm{ha}$ as soil application. Plant height of sweet sorghum was significantly taller due to RDF+ $\mathrm{ZnSO}_{4} \quad 15 \mathrm{~kg} / \mathrm{ha}+\mathrm{FeSO}_{4} \quad 15 \mathrm{~kg} / \mathrm{ha}$ soil application as compared to control, NPK 120:60:40 kg/ha (RDF), RDF+0.2\% $\quad \mathrm{ZnSO}_{4}$ and $\mathrm{RDF}+0.4 \% \mathrm{FeSO}_{4}$ foliar spray at $15 \& 30$ DAS during both the years. Plant height was increased 26.76, 8.98 and 10.37 per cent respectively over control, $\mathrm{RDF}+0.2 \% \mathrm{ZnSO}_{4}$ and $\mathrm{RDF}+0.4 \% \mathrm{FeSO}_{4}$ foliar spray at $15 \& 30$ DAS during 2012. This might be due to precise soil and foliar application of $\mathrm{Zn}$ and $\mathrm{Fe}$ individually or in combination along with RDF enhances plant growth parameters (plant height, leaf area index, L:S ratio, dry matter etc.) over control (Mali and Dashora, 2003). Similar results were also reported by Sumeriya and Singh (2008) and Syed Ismail et al., (2001).

Dry matter and crude protein content were differed significantly under different treatments level during both the years. Treatment $\mathrm{RDF}+\mathrm{ZnSO}_{4} 15 \mathrm{~kg} / \mathrm{ha}+\mathrm{FeSO}_{4} 15$ $\mathrm{kg} / \mathrm{ha}$ as soil application recorded maximum dry matter content of 27.78 percent (2012) and 28.37 per cent during 2013 as well as crude protein content of 9.79 per cent and 9.84 per cent during 2012 and 2013, respectively, followed by $\mathrm{RDF}+\mathrm{ZnSO}_{4} 25 \mathrm{~kg} / \mathrm{ha}$.

The increased in dry matter content was 31.85 and 30.45 per cent, respectively by $\mathrm{RDF}+\mathrm{ZnSO}_{4} 15 \mathrm{~kg} / \mathrm{ha}+\mathrm{FeSO}_{4} 15 \mathrm{~kg} / \mathrm{ha}$ as soil application over control during both the years. Application of RDF in combination with $\mathrm{ZnSO}_{4} 15 \mathrm{~kg} / \mathrm{ha}+\mathrm{FeSO}_{4} 15 \mathrm{~kg} / \mathrm{ha}$ as soil application significantly increased crude protein content as compared to remaining treatments except $\mathrm{RDF}+\mathrm{ZnSO}_{4} 25 \mathrm{~kg} / \mathrm{ha}$ and $\mathrm{RDF}+\mathrm{ZnSO}_{4} 15 \mathrm{~kg} / \mathrm{ha}+0.2 \% \mathrm{ZnSO}_{4}$ spray at 15 and 30 DAS during both the years. Crude protein content was increased 21.86 and 20.43 per cent (2012) and 21.84 and 20.63 per cent (2013) over control and NPK 120:60:40 kg/ha (RDF), respectively. Zn has important role in basic plant life processes like nitrogen metabolism and uptake of nitrogen resulted increase of crude protein content in plant (Pawar et al., 2015). The results are conformity with the finding of Sharifi and Taghizadeh (2009).

The green fodder, dry fodder and crude protein yield of sweet sorghum were influenced significantly due to soil and foliar application of micronutrients (Table 2) during both the years. Treatment $\mathrm{RDF}+\mathrm{ZnSO}_{4} 15$ $\mathrm{kg} / \mathrm{ha}+\mathrm{FeSO}_{4} \quad 15 \mathrm{~kg} / \mathrm{ha}$ as soil application significantly recorded the highest green fodder yield (613.36 q/ha in 2012 and 624.63 q/ha in 2013), dry fodder yield (170.39 and 177.21 q/ha in 2012 and 2013, respectively) as well as crude protein yield $16.65 \mathrm{q} / \mathrm{ha}$ (2012) and $17.44 \mathrm{q} / \mathrm{ha}$ (2013), followed by $\mathrm{RDF}+\mathrm{ZnSO}_{4}$ $25 \mathrm{~kg} / \mathrm{ha}$. Green fodder yield was increased 49.39 and 18.80 per cent during 2012 and 49.47 and 18.70 per cent during 2013 by $\mathrm{RDF}+\mathrm{ZnSO}_{4} 15 \mathrm{~kg} / \mathrm{ha}+\mathrm{FeSO}_{4} 15 \mathrm{~kg} / \mathrm{ha}$ as soil application over control and NPK 120:60:40 $\mathrm{kg} / \mathrm{ha}$ (RDF), respectively. This might be due to $\mathrm{Zn}$ has a key role in photosynthesis and metabolic process augments the production of photosynthates and their translocation to different plant parts and Fe plays a vital role in catalytic function in biological oxidation and reduction in plant as well as it is constituent of a large number of metabolically active compounds like cytochromes, heme and nonheme enzymes and other functional metalloproteins, which ultimately increases the green fodder and dry fodder yield of forage crops (Meena et al., 2013). The increase in crude protein yield was 72.37 and 72.47 per cent by $\mathrm{RDF}+\mathrm{ZnSO}_{4} \quad 15$ $\mathrm{kg} / \mathrm{ha}+\mathrm{FeSO}_{4} 15 \mathrm{~kg} / \mathrm{ha}$ as soil application over control during 2012 and 2013, respectively. 
Table.1 Growth and quality parameters of sweet sorghum as influenced by soil and foliar application of micronutrients

\begin{tabular}{|c|c|c|c|c|c|c|c|c|c|c|}
\hline \multirow[t]{2}{*}{ Treatments } & \multicolumn{2}{|c|}{$\begin{array}{l}\text { Plant height } \\
\quad(\mathrm{cm})\end{array}$} & \multicolumn{2}{|c|}{$\begin{array}{c}\text { Stem } \\
\text { Diameter } \\
(\mathrm{cm} / \text { stem })\end{array}$} & \multicolumn{2}{|c|}{ L:S ratio } & \multicolumn{2}{|c|}{$\begin{array}{l}\text { Dry matter } \\
\text { content }\end{array}$} & \multicolumn{2}{|c|}{$\begin{array}{l}\text { Crude } \\
\text { protein } \\
\text { content }\end{array}$} \\
\hline & 2012 & 2013 & 2012 & 2013 & 2012 & 2013 & 2012 & 2013 & 2012 & 2013 \\
\hline Control & 263.66 & 271.57 & 1.05 & 1.08 & 0.22 & 0.25 & 18.98 & 19.73 & 7.65 & 7.69 \\
\hline NPK 120:60:40 kg/ha (RDF) & 326.66 & 336.03 & 1.14 & 1.16 & 0.23 & 0.26 & 25.98 & 26.40 & 7.79 & 7.81 \\
\hline $\mathrm{RDF}+\mathrm{ZnSO}_{4} 25 \mathrm{~kg} / \mathrm{ha}$ & 357.33 & 368.05 & 1.22 & 1.26 & 0.29 & 0.33 & 27.72 & 28.20 & 9.40 & 9.42 \\
\hline $\mathrm{RDF}+\mathrm{FeS0}_{4} 25 \mathrm{~kg} / \mathrm{ha}$ & 350.66 & 361.18 & 1.16 & 1.20 & 0.29 & 0.33 & 27.50 & 28.04 & 9.14 & 9.18 \\
\hline $\mathrm{RDF}+0.2 \% \mathrm{ZnSO}_{4}$ foliar spray at15and $30 \mathrm{DAS}$ & 327.66 & 337.49 & 1.15 & 1.19 & 0.25 & 0.28 & 25.50 & 26.00 & 8.13 & 8.17 \\
\hline $\mathrm{RDF}+0.4 \% \mathrm{FeSO}_{4}$ foliar spray at15 and 30DAS & 322.66 & 332.34 & 1.17 & 1.20 & 0.27 & 0.31 & 25.77 & 26.51 & 7.95 & 7.98 \\
\hline $\begin{array}{l}\mathrm{RDF}+0.2 \% \mathrm{ZnSO}_{4}+0.4 \% \mathrm{FeSO}_{4} \text { foliar spray at15and } 30 \\
\text { DAS }\end{array}$ & 343.33 & 353.63 & 1.19 & 1.23 & 0.28 & 0.32 & 26.46 & 27.78 & 8.58 & 8.61 \\
\hline $\begin{array}{l}\mathrm{RDF}+\mathrm{ZnSO}_{4} 15 \mathrm{~kg} / \mathrm{ha}+0.2 \% \mathrm{ZnSO}_{4} \text { foliar spray at } 15 \\
\text { and } 30 \mathrm{DAS}\end{array}$ & 354.66 & 365.30 & 1.18 & 1.22 & 0.24 & 0.27 & 23.10 & 23.55 & 9.16 & 9.19 \\
\hline $\begin{array}{l}\mathrm{RDF}+\mathrm{FeSO}_{4} 15 \mathrm{~kg} / \mathrm{ha}+0.4 \% \mathrm{FeS0}_{4} \text { foliar spray at } 15 \text { and } \\
30 \text { DAS }\end{array}$ & 345.66 & 356.03 & 1.18 & 1.21 & 0.23 & 0.26 & 26.97 & 27.70 & 8.97 & 9.01 \\
\hline $\mathrm{RDF}+\mathrm{ZnSO}_{4} 15 \mathrm{~kg} / \mathrm{ha}+\mathrm{FeSO}_{4} 15 \mathrm{~kg} / \mathrm{ha}$ soil application & 360.00 & 370.80 & 1.58 & 1.63 & 0.30 & 0.34 & 27.78 & 28.37 & 9.79 & 9.84 \\
\hline SEm \pm & 10.6 & 10.92 & 0.05 & 0.06 & 0.03 & 0.03 & 0.52 & 0.38 & 0.22 & 0.22 \\
\hline C.D. at 5\% & 31.5 & 32.45 & NS & NS & NS & NS & 1.55 & 1.14 & 0.66 & 0.67 \\
\hline
\end{tabular}


Table.2 Yields and economics of sweet sorghum as influenced by soil and foliar application of micronutrients

\begin{tabular}{|c|c|c|c|c|c|c|c|c|c|c|c|c|}
\hline \multirow[t]{2}{*}{ Treatments } & \multicolumn{2}{|c|}{$\begin{array}{l}\text { Green fodder } \\
\text { yield (q/ha) }\end{array}$} & \multicolumn{2}{|c|}{$\begin{array}{l}\text { Dry fodder } \\
\text { yield (q/ha) }\end{array}$} & \multicolumn{2}{|c|}{$\begin{array}{l}\text { Crude protein } \\
\text { yield (q/ha) }\end{array}$} & \multicolumn{2}{|c|}{$\begin{array}{c}\text { Cost of } \\
\text { cultivation } \\
\text { (Rs./ha) }\end{array}$} & \multicolumn{2}{|c|}{$\begin{array}{l}\text { Net return } \\
\text { (Rs./ha) }\end{array}$} & \multicolumn{2}{|c|}{$\begin{array}{l}\mathrm{B}: \mathrm{C} \\
\text { ratio }\end{array}$} \\
\hline & 2012 & 2013 & 2012 & 2013 & 2012 & 2013 & 2012 & 2013 & 2012 & 2013 & 2012 & 2013 \\
\hline Control & 310.42 & 315.63 & 58.92 & 62.27 & 4.60 & 4.80 & 6500 & 6663 & 10573 & 10901 & 1.62 & 1.64 \\
\hline NPK 120:60:40 kg/ha (RDF) & 498.04 & 507.84 & 129.39 & 134.07 & 10.11 & 10.47 & 10005 & 10255 & 20027 & 20648 & 2.00 & 2.01 \\
\hline $\mathrm{RDF}+\mathrm{ZnSO}_{4} 25 \mathrm{~kg} / \mathrm{ha}$ & 538.48 & 548.25 & 149.59 & 154.61 & 14.01 & 14.57 & 10375 & 10634 & 20891 & 21539 & 2.01 & 2.03 \\
\hline $\mathrm{RDF}+\mathrm{FeSO}_{4} 25 \mathrm{~kg} / \mathrm{ha}$ & 527.34 & 537.89 & 145.02 & 150.82 & 13.27 & 13.84 & 10155 & 10409 & 18849 & 19433 & 1.85 & 1.87 \\
\hline $\mathrm{RDF}+0.2 \% \mathrm{ZnSO}_{4}$ foliar spray at 15 and $30 \mathrm{DAS}$ & 499.16 & 507.18 & 127.29 & 131.87 & 10.36 & 10.77 & 9630 & 9871 & 16494 & 17005 & 1.71 & 1.72 \\
\hline $\mathrm{RDF}+0.4 \% \mathrm{FeSO}_{4}$ foliar spray at 15 and $30 \mathrm{DAS}$ & 474.98 & 484.48 & 122.40 & 128.44 & 9.74 & 10.25 & 10195 & 10450 & 17369 & 17907 & 1.70 & 1.71 \\
\hline $\mathrm{RDF}+0.2 \% \mathrm{ZnSO}_{4}+0.4 \% \mathrm{FeSO}_{4}$ foliar spray at 15 and 30DAS & 501.16 & 511.18 & 132.61 & 136.89 & 11.38 & 11.78 & 9670 & 9912 & 17894 & 18449 & 1.85 & 1.86 \\
\hline $\mathrm{RDF}+\mathrm{ZnSO}_{4} 15 \mathrm{~kg} / \mathrm{ha}+0.2 \% \mathrm{ZnSO}_{4}$ foliar spray at 15 and $30 \mathrm{DAS}$ & 540.78 & 549.60 & 145.85 & 152.24 & 13.21 & 13.85 & 9530 & 9768 & 20708 & 21350 & 2.17 & 2.19 \\
\hline $\mathrm{RDF}+\mathrm{FeSO}_{4} 15 \mathrm{~kg} / \mathrm{ha}+0.2 \% \mathrm{ZnSO}_{4}$ foliar spray at 15 and $30 \mathrm{DAS}$ & 538.56 & 547.33 & 142.50 & 146.57 & 12.77 & 13.19 & 9770 & 10014 & 19851 & 20466 & 2.02 & 2.04 \\
\hline $\mathrm{RDF}+\mathrm{ZnSO}_{4} 15 \mathrm{~kg} / \mathrm{ha}+\mathrm{FeSO}_{4} 15 \mathrm{~kg} / \mathrm{ha}$ soil application & 613.36 & 624.63 & 170.02 & 177.21 & 16.65 & 17.44 & 10430 & 10691 & 23305 & 24027 & 2.23 & 2.25 \\
\hline SEm \pm & 24.25 & 24.74 & 6.70 & 6.97 & 0.43 & 0.30 & - & - & 1333 & 1374 & 0.13 & 0.12 \\
\hline C.D. at $5 \%$ & 72.04 & 73.48 & 19.80 & 20.59 & 1.27 & 0.90 & - & - & 3962 & 4085 & 0.40 & 0.38 \\
\hline
\end{tabular}


It might be due to highest dry matter production and crude protein content because crude protein yield is function of crude protein content and dry matter yield. Similar results were also reported by Pawar et al., (2015) and Joshi et al., (2012).

Net return (Rs/ha) and B:C ratio were differed significantly under different treatments level during both the years. Cost of cultivation (Rs/ha) was higher under the $\mathrm{RDF}+\mathrm{ZnSO}_{4} 15$ $\mathrm{kg} / \mathrm{ha}+\mathrm{FeSO}_{4} 15 \mathrm{~kg} / \mathrm{ha}$ as soil application and lower under control treatment. Net return (Rs/ha) was significantly obtained higher under RDF+ZnSO 15 kg/ha+FeSO 415 kg/ha as soil application compared to other treatments but it was at par with NPK 120:60:40 kg/ha (RDF), $\mathrm{RDF}+\mathrm{ZnSO}_{4} \quad 25$ $\mathrm{kg} / \mathrm{ha}, \mathrm{RDF}+\mathrm{ZnSO} \mathrm{n}_{4} 15 \mathrm{~kg} / \mathrm{ha}+0.2 \% \quad \mathrm{ZnSO}_{4}$ spray at 15 \& 30 DAS and $\mathrm{RDF}+\mathrm{FeSO}_{4} 15$ $\mathrm{kg} / \mathrm{ha}+0.4 \% \quad \mathrm{FeSO}_{4}$ spray at 15 \& $30 \mathrm{DAS}$ during both the years. The maximum $\mathrm{B}: \mathrm{C}$ ratio (2.13 in 2012 and 2.25 in 2013) was recorded in soil application of $\mathrm{ZnSO}_{4}$ and $\mathrm{FeSO}_{4}$ each $15 \mathrm{~kg} / \mathrm{ha}$ with RDF during both the years, followed by $\mathrm{RDF}+\mathrm{ZnSO}_{4} \quad 15 \mathrm{~kg} / \mathrm{ha}+0.2 \%$ $\mathrm{ZnSO}_{4}$ spray at 15 and 30 DAS.

On the basis of the present investigation, it is concluded that growing of sweet sorghum with application of RDF (NPK 120:60:40 $\mathrm{kg} / \mathrm{ha}$ ) in combination with $\mathrm{ZnSO}_{4} 15 \mathrm{~kg} / \mathrm{ha}+$ $\mathrm{FeSO}_{4} 15 \mathrm{~kg} / \mathrm{ha}$ as soil application showed better proposition of achieving higher green fodder, dry matter and crude protein yield as well as quality of fodder.

\section{References}

AOAC 1965. Official methods of analysis. 10th ed. Association of official Agricultural Chemicals. Washington, DC, USA.

El-Fouly, M.M. and El-Sayed, A.A. 1997. Foliar fertilization: An environmentally friendly application of fertilizers. (In) Proceedings of dahlia Greidinger International Symposium on Fertilization and Environment held during 24-27 March, Haifa, Israel, John I (ed.). pp. 346-57.

Jackson, M.L. 1973. Soil chemical analysis constable and Co. Ltd. Prentice Hall of India Pvt. Ltd New Delhi.

Jat, S.L, Shivay, Y.S. and Parihar, C.M. 2014. Effect of dual-purpose summer legumes and zinc fertilization on system productivity, economics and nutrient use-efficiencies of rice (Oryza sativa)- wheat (Triticum aestivum) cropping system. Indian Journal of Agricultural Sciences. 84(8): 942-50.

Joshi, Y.P., Kumar, S. and Faruqui, S.A. 2012. Production potential and economic feasibility of year round forage production system in Tarai region of Uttarakhand. Range management and Agroforestry. 33(1): 65-68.

Koeppen, K., Reinhardt, G. and Gaertner, S. 2009. Assessment of energy and greenhouse gas inventories of sweet sor-ghum for first and second generation bioethanol. FAO Environmental and Natural Resources Service Series. No. 30, Rome: FAO.

Mali, A. L., and Dashora, L.N. 2003. Annals of Agricultural Research. New Series. 24: 421-422.

Meena, S.K., Mundra, S.L. and Singh, P. 2013. Response of maize (Zea mays L.) to nitrogen and zinc fertilization. Indian Journal of Agronomy. 58: 127128.

Olsen, S.R., Cole, C.V., Watanabe, F.S. and Dean, L.A. 1954. Estimation of available phosphorus in soils by extraction with sodium bicarbonate. USDA. Circular. Govt printing office Washington D. C. 939: 1-19.

Pandey, N., Pathac G.C., Singh, A.K. and Sharma, C.P. 2002. Enzymatic changes in response to zinc nutrition. Journal of 
Plant Physiology. 159: 1151-1153.

Pawar, A. Adsul, P.B. and Gaikwad, G.K. 2015. Nutrient content, uptake and biochemical composition in kharif sorghum affected by soil and foliar zinc and iron in drought prone Marathwada area of Maharashtra. Indian Journal Dryland Agricultural Research and Development. 30(2) : 7483.

Rathod, K.B., Napahde, P.S., Jadhao, S.D., Jadhao, V.O. and Kharat, B.S. 2005. Uptake of nutrients as influenced by application of zinc and iron in sorghum. Annals of Plant Physiology. 19(2): 184-186.

Sharifi, R.S. and Taghizadeh, R. 2009. Response of maize (Zea mays L.) cultivars to different levels of nitrogen fertilizer. Journals of Food, Agriculture and Environment. 7 (3-4): 518-521.
Subbiah, B.V. and Asija, H.L. 1956. A rapid procedure for estimation of the available nitrogen in soils. Current Science. 25: 259-260.

Sumeriya, H.K. and Singh, P. 2008. Effect of plant geometry and fertility levels on yield attributes, yield, protein content and yield of promising sorghum genotypes under rainfed condition. International Journal of Tropical Agriculture. 26 (3 - 4): 403-407.

Syed, I., Adsul, P.B., Shinde, G.G. and Deshmukh, A.S. 2001. Impact of FYM and Fertilizer nitrogen on yield and soil properties of sorghum grown on Vertisol. International Sorghum and Millets News letter. 42:29-31.

Walkley, A.J. and Black, I.A. 1934. Estimation of soil organic carbon by the chromic acid titration method. Soil Science. 37: 29-38.

\section{How to cite this article:}

Brajkishor Prajapati and Kewalanand. 2019. Effect of Micronutrients on Growth and Yield of Sweet Sorghum under Tarai Region of Uttarakhand. Int.J.Curr.Microbiol.App.Sci. 8(12): 1693-1699. doi: https://doi.org/10.20546/ijcmas.2019.812.203 